\title{
ANALISIS GENDER DALAM BINGKAI KEWARGANEGARAAN DAN PEMBANGUNAN HUKUM DI INDONESIA
}

\author{
Rahmat Wijayanto J. \\ Pendidikan Pancasila dan Kewarganegaraan \\ Program Paskasarjana Universitas Negeri Yogyakarta \\ rahmatwijayanto.j@gmail.com
}

\begin{abstract}
Abstrak
Indonesia adalah negara hukum yang dalam pelaksanaan kehidupan bernegara dan bermasyarakat akan senantiasa dilandasi kepatuhan terhadap hukum. Dalam mewujudkan negara hukum diperlukan perangkat hukum yang digunakan untuk mengatur kehidupan dan mengedapankan prinsip keadilan di tengah kehidupan setiap warga negara Indonesia. Perangkat hukum tersebut adalah peraturan perundang-undangan yang tidak mengesampingkan fungsi yurisprudensi. Selayaknya peraturan hukum yang berlaku di Indonesia pelaksanaan dan keberadaan kesetaraan gender dalam setiap sendi kehidupan warga negara diatur pula dalam peraturan perundang-undangan. Setiap orang yang berkewarganegaraan Indonesia memiliki hak dan kewajiban yang sama baik dalam bidang politik, ekonomi, sosial ataupun hukum. Faham feminisme yang menuntut kesetaraan gender terhadap hak-hak kewarganegaraan yang diperoleh sebagai warga negara melalui kesamaan di mana perempuan sebagai warga negara juga ingin diakui oleh lembaga politik, hukum dan sosial yang selama ini lebih didominasi oleh laki-laki. Penulisan ini bertujuan uantuk memaparkan mengenai gender dan kesetaraan dalam bingkai hukum positif dan kewarganegaraan Indonesia dan aplikasinya dalam kehidupan setiap warga negara dengan menggunakan metode kajian kepustakaan.
\end{abstract}

Kata Kunci: Gender, Kesetaraan, Kewarganegaraan, Hukum Indonesia

\section{A. Pendahuluan}

Reformasi ditandai dengan adanya perubahan paradigma dalam penyelenggaraan negara yang lebih demokratis dan berdasarkan prinsip negara hukum serta dalam upaya menegakkan supremasi hukum. Selain itu perlindungan hak asasi manusia dan persamaan kesederajatan di depan hukum bagi setiap warga negara harus senantiasa ditegakkan dengan prinsip keadilan. Wujud perubahan dalam konteks konstitusional atau dasar hukum tertinggi di Indonesia yakni dengan terlaksananya amandemen UUD tahun 1945. Perubahan itu mempunyai maksud dan tujuan untuk menyempurnakan atuarn dasar mengenai tatanan negara dalam mencapai tujuan nasional yang tertuang dalam pembukaan UUD tahun 1945, penyempurnaan mengenai aturan dasar mengenai jaminan dan pelaksanaan kedaulatan rakyat, penyelenggaraan negara secara demokratis dan modern, jaminan konstitusional dan kewajiban negara mewujudkan kesejahteraan sosial. Penyempurnaan tersebut untk melengkapi aturan dasar yang sangat 
penting dalam penyelenggaraan negara, menyempurnakan aturan dasar mengenai kehidupan berbangsa dan bernegara.

Pelaksanaan penyempurnaan dalam konstitusi negara Indonesia menyentuh pola persoalaan kewarganegaraan yang harus ditata kembali sesuai dengan tuntutan demokratisasi dan kebutuhan reformasi. Hal itu agar masalah hak-hak dan perlindungan warga negara dapat diposisikan secara tepat di dalam rangka perlindunganh hak asasi manusia tanpa mengganggu kestabilan dan kedaulatan negara Kesatuan Republik Indonesia. Gagasan tersebut kemudian diwujudkan dengan diberlakukannya peraturan perundang-undangan tentang kewarganegaraan yang secara resmi dituangkan dalam Undang-Undang nomor 12 tahun 2006 tentang Kewarganegaraan Republik Indonesia. Undang-undang tersebut menggantikan posisi UndangUndang nomor 62 tahun 1958.

Ketegasan dan kepastian dalam Undang-Undang Dasar 1945 bahwa negara Indonesia memberikan jaminan kepada setiap orang mempunyai hak yang sama di depan hukum. Namun dalam kenyataannya hingga saat ini isu mengenai kesetaraan gender hanya baru sebatas Rancangan Undang-Undang di DPR dan belum disahkan hingga saat ini menjadi UndangUndang. Namun dalam beberapa aspek gender sudah masuk dalam beberapa peraturan perundang-undangan namun belum begitu spesifik dan terperinci. Meskipun demikian bila menelisik dari berbagai bidang khususnya dalam kajian ini ialah kewarganegaraan Indonesia dan gender sebenarnya dalam Undang-Undang nomor 12 tahun 2006 tentang Kewarganegaraan Republik Indonesia telah memberlakukan kesetaraan gender yang tepat dalam menempatkan hak-hak antara laki-laki dan perempuan.

Gender dalam arti sempit ialah mengenai jenis kelamin manusia yang merupakan pemberian Tuhan Yang Maha Esa. UNESCO menjelaskan sendiri arti gender "gender refers to the roles and responsibilities of men and woman that are in our family, our societies and out cultures. The concept of genders also includes the expectations held about the characteristics, aptitudes and likely behaviours of both women and men (feminity and masculinity)". Yakni gender merujuk pada peran dan tanggung jawab laki-laki dan perempuan yang terdapat dalam keluarga, masyarakat dan budaya. Konsep gender juga mencakup harapan yang dimiliki tentang karakteristik, kemampuan dan kemungkinan perilaku keduanya wanita dan pria (feminitas dan maskulinitas). Bentuk lain mengenai gender yakni menurut Kristeva yakni gender merupakan suatu konsep kultural yang merujuk pada karakteristik yang membedakan antara laki-laki dan perempuan baik secara biologis, perilaku, mentalitas dan sosial budaya (Tong, 2004: 42).

Sebagai warga negara Indonesia sudah semestinya setiap orang yang memiliki status kewarganegaraan Indonesia dan diakui oleh hukum Indonesia memiliki kesempatan yang sama 
dalam setiap sendi kehidupan berbangsa dan bernegara di Indonesia. Dalam hal ini prakteknya masih sering dijumpai bias gender dalam penerapan hukum di Indonesia baik dalam konteks kewarganegaraan maupun konteks politik, ekonomi dan sosial. Bappenas Indonesia dalam laman web resminya menuturkan bahwa indeks kesetaraan gender di Indonesia mengalam peningkatan dalam kurun waktu tahun 2013-2015 dari segi pendidikan, ekonomi, dan kesehatan. Kesetaraan gender tidak hanya pada level kebutuhan akan hidup atau ekonomi, kesehatan, dan pendidikan semata. Namun kesetaraan gender juga merujuk mengenai kehidupan berpolitik dan hukum dalam bingkai negara hukum Indonesia sebagaimana yang ditegaskan dalam Undang-Undang Dasar 1945 Pasal 1 Ayat 3 yakni “negara Indonesia adalah negara hukum”.

\section{B. Pembahasan}

\section{Konsep Gender}

Gender merupakan salah satu isu, yang hangat dan menarik diperbincangkan. Istilah gender mengandung arti seperangkat sikap, peran, tanggung jawab, fungsi, hak dan perilaku yang melekat pada diri laki-laki dan perempuan akibat bentukan budaya atau lingkungan masyarakat tempat dimana manusia itu tumbuh dan dibesarkan. Setiap masyarakat selalu ada pembagian kerja antara laki-laki dan perempuan, sehingga dikenal dengan peran gender yang berbeda antara laki-laki dan perempuan. Singkat kata gender ialah perbedaan kelamin, namun lebih dalam lagi gender mendekati arti jenis kelamin dari kaca mata sosial (interpensi sosio kultural), seperangkat peran seperti apa yang seharusnya dan apa yang tidak seharusnya dilakukan laki-laki dan perempuan (Fakih, 1998:8).

Perbedaan gender sesungguhnya merupakan hal yang biasa atau suatu kewajaran sepanjang tidak menimbulkan ketidakadilan gender. Ketidakadilan gender dapat menyebabkan pembagian peran dan tanggung jawab yang berlebih pada salah satu pihak, yakni perempuan atau laki-laki. Perbedaan gender ternyata telah menyebabkan munculnya berbagai ketidakadilan gender yang terjadi dalam keluarga dan masyarakat. Ketidakadilan gender tentu perlu diperjuangkan menjadi keadilan atau kesetaraan gender (Zakia, 2011: 39).

Gender adalah perbedaan peran, fungsi, persifatan, kedudukan, tanggung jawab dan hak perilaku,baik perempuan, maupun laki-laki yang dibentuk, dibuat, dan disosialisasikan oleh norma, adat kebiasaan, dan kepercayaan masyarakat setempat. Dalam kaitan ini, konsep gender berhubungan denganperan dan tugas yang pantas/tidak pantas, baik untuk laki-laki, maupun perempuan. Adapun relasi gender adalah hubungan antara laki-laki dan perempuan berkaitan dengan pembagian peran yang dijalankan masing-masing pada berbagai tipe dan struktur 
keluarga (keluarga miskin/kaya, keluarga desa/kota, keluarga lengkap/tunggal, keluarga punya anak/tidak punya anak, keluarga pada berbagai tahapan life cycle). Bahkan, relasi gender ini juga diperluas secara bertahap berdasarkan luasan ekologi, mulai dari mikro, meso, ekso, dan makro (keluarga inti, keluarga besar, masyarakat regional, masyarakat nasional, bangsa dan negara dan masyarakat internasional) (Puspitawati, 2010: 18).

Gender diartikan pula sebagai konstruksi sosio kultural yang membedakan karakteristik maskulin dan feminin. Gender berbeda dengan seks atau jenis kelamin laki-laki dan perempuan yang bersifat biologis. Kristeva menjelaskan gender ialah konsep kultural yang merujuk pada karakteristik yang membedakan laki-laki dan perempua baik secara biologis, perilaku, mentalitas dan sosial budaya (Tong, 2002: 42). Dengan demikian gender secara jelas ialah merupakan suatu pembeda antara kaum laki-laki dan kaum perempuan, yang kemudian dilihat dari fungsinya dalam menjalani kehidupannya sehari-hari dalam bernegara dan bermasyarakat.

\section{Kesetaraan Gender}

Untuk mewujudkan kesetaraan dan keseimbangan dalam bidang gender maka perlu diperhatikan parameternya, yakni dalam resume parameter kesetaraan gender dalam pembentukan peraturan perundang-undangan yang ditulis oleh kementerian hukum dan hak asasi manusia Republik Indonesia, kementerian pemberdayaan perempuan dan perlindungan anak Republik Indonesia lalu kementerian dalam negari Republik Indonesia menjelaskan bahwa kesetaraan gender yakni suatu keadaaan setara antara perempuan dan laki-laki dalam hak (hukum) dan kondisi kualitas hidup, (2012). Sedangkan untuk prinsip-prinsip kesetaraan gender adalah meliputi:

1. Hak asasi perempuan yakni hak asasi manusia yang dilahirkan bebas, mempunyai harkat, martabat dan hak yang sama, baik laki-laki maupun perempuan. Dengan begitu negara wajib menjamin persamaan pemenuhan hak laki-laki dan perempuan di bidang ekonomi, sosial budaya, sipil dan politik serta bidang-bidang lainnya.

2. Prinsip kesetaraan gender, pada dasarnya upaya memperjuangkan hak-hak perempuan dan kesetaraan gender yang terkandung dalam Konvensi CEDAW, yakni:

1) Prinsip kesetaraan subtantif

Yakni langkah yang dilakukan untuk menganalisis hak perempuan yang ditujukan untuk mengatasi perbedaan dan kesenjangan yang merugikan pihak perempuan. Di mana negara berkewajiban untuk hal ini memberi kesempatan dan akses yang sama pada perempuan dan laki-laki baik dalam bingkai hukum dan kondisi hidup.

2) Prinsip non diskriminasi 
Yakni diskriminasi tidak terbatas dalam kehidupan publik tetapi mencakup pula tindakantindakan yang dilakukan oleh pelaku privat seperti keluarga, korporasi bisnis dan masyarakat. Diskriminasi mencakup hukum tertulis, asumsi sosial budaya mengenai perempuan dan norma-norma yang diperuntukkan perempuan dalam kehidupan seharihari.

3) Prinsip kewajiban negara

Dalam hal ini negara Indonesia yang merupakan negara hukum sudah tentu harus menjamin kesetaraan dan kesempatan yang sama bagi perempuan dan laki-laki dalam berbagai sendi kehidupan berbangsa dan bernegara. Negara menjamin hak perempuan melalui hukum/peraturan perundang-undangan kebijakan serta menjamin hasilnya, menjamin pelaksanaan praktis dari hak-hak tersebut dengan aturan khusus sementara, menciptakan lingkungan yang kondusif untuk meningkatkan kesempatan dan akses untuk hak-hak tersebut, negara tidak saja harus akuntabel dan mengaturnya di tatanan kehidupan publik, melainkan juga di ranah privat (keluarga ) dan sektor swasta.

Mewujudkan Kesetaraan dan Keadilan gender (KKG) bukanlah merupakan suatu yang mudah, tetapi memerlukan perjuangan yang ekstra keras karena hal ini berkaitan erat dengan perubahan nilai budaya atau konstruksi sosial budaya yang telah berurat akar di masyarakat. Namun demikian, karena semua nilai budaya yang ada di masyarakat adalah bentukan manusia, maka pada prinsipnya hal ini bisa diubah tetapi memerlukan proses yang panjang. Melalui upaya yang serius dan berkesinambungan maka secara lambat laun ideologi gender yang bersifat merugikan salah satu jenis kelamin akan dapat dikikis sehingga pada gilirannya kesetaraan dan keadilan gender dimasyarakat Indonesia pada umumnya dan di Bali khususnya akan dapat terwujud. Terwujudnya kesetaraan dan keadilan gender berarti masyarakat kita telah mampu memenuhi salah satu kesepakatan Millenium Development Goals (MDGs) yang telah menjadi komitmen Internasional (Arjani, 2008: 116). Pengertian secara harfiah kata setara disebut juga dengan seimbang, tidak berat sebelah dan tidak membeda-bedakan. Kalau dikaitkan dengan gender berarti tidak melihat dari jenis kelamin yang bersifat biologis akan tetapi dilihat dari kemampuan dan kualitas dari seseorang (Suryani, 2010: 8).

Pujiastuti (2012: 82) melalui penelitiannya memaparkan bahwa, pergeseran cara pandang atas peran gender terus berkembang secara dinamis di masyarakat, termasuk di birokrasi, pro-kontra terhadap kesetaraan gender akan terus ada sepanjang jaman. Ketimpangan antara perempuan dan laki-laki terutama di ranah publik juga akan terus menjadi perdebatan karena meskipun ada pengakuan kesetaraan hak, seringkali tidak diikuti oleh adanya gerakan untuk memberikan kesempatan yang sama. Itulah sebabnya meskipun jumlah perempuan di 
Birokrasi terus bertambah jumlahnya, masih tidak mudah bagi mereka untuk menembus sebagi elit.

\section{Konsep Kewarganegaraan dan Gender}

Gagasan kewarganegaraan muncul dari Barat. Para teoritisi kontemporer menggambarkan gagasan ini sebagai “aspek kunci dari pemikiran politik Barat sejak pembentukan budaya politik Yunani klasik” dan "satu dari pusat pengorganisiran fitur dari wacana politik Barat” (Lister, 2003). Sosiolog Inggris, T.H Marshall, mendefinisikan kewarganegaraan sebagai "status yang diberikan pada orang yang menjadi anggota penuh sebuah masyarakat. Semua yang memiliki status tersebut memiliki hak dan tugas yang sama dengan status yang dianugerahkan.”Dalam konteks keanggotan ini, menurut Hall and Held, “politik kewarganegaraan dimulai.” Ini bukan hanya melibatkan tatanan hukum yang mengatur hubungan antara individu dengan negara, tapi juga tatanan hubungan sosial antara individu dengan negara dan antar individu warga negara. Dengan demikian relasi ini bisa dinegosiasikan (Stasiulis dan Bakan, 1997).

Sementara Adrian Oldfield (1990) mengonsepsikan dua pendekatan, yakni kewarganegaraan sebagai status dan kewarganegaraan sebagai praktik. Pendekatan pertama memprioritaskan hak warga negara sebagai individu, sedangkan pendekatan kedua pada kepentingan masyarakat yang lebih luas. Tetapi gagasan kewarganegaraan kerap dikritik terlalu individual dan anti sosial karena doktrinnya tentang hak individu. Kewarganegaraan, dan komunitarianisme sebagai turunannya, berasal dari doktrin individualisme posesif dan kebebasan yang negatif. Mereka adalah akomodasi intelektual dengan kebutuhan untuk pengaturan sosial, tetapi pada intinya mereka tetap anti-sosial, baik dalam makna sosiologis maupun popular (Byrne, 2005).

Itulah mengapa upaya melihat kewarganegaraan sebagai sebuah proses dan bukan semata-mata hasil yang penting untuk dilakukan, mengombinasikan elemen dari dua tradisi sejarah kewarganegaraan, yakni tradisi republikan partisipatoris dan tradisi hak-hak sosialliberal, Ini merupakan upaya untuk melihat bahwa warga negara bukan sekadar pemegang hakhak pasif, tapi juga aktif terlibat dengan lembaga politik dan kesejahteraan, baik sebagai individu maupun kelompok. Dalam konteks perspektif feminis, menurut Lister (2003), pendekatan kewarganegaraan juga ingin dilihat apakah memberi kemungkinan posisi perempuan sebagai agen (perubahan) dibanding semata-mata sebagai korban dari diskriminasi dan opresi dari lembaga politik, ekonomi, maupun sosial yang didominasi laki-laki. 
Ada dua jenis pendekatan kewarganegaraan, yakni pendekatan hak dan pendekatan kewajiban. Pendekatan hak berasal dari tradisi politik liberal yang muncul pada abad ke-17 sebagai upaya negara berdaulat dalam menjamin kebebasan warganya. Negara memberikan hak sipil dan hak politik bagi warganya.Sementara pendekatan kewarganegaraan sebagai kewajiban berakar pada tradisi republikan yang lebih tua dari era Yunani klasik dimana partisipasi politik merupakan kewajiban warga negara dan ekspresi penuh warga negara sebagai mahluk politik yang mewakili esensi kewarganegaraan sebagaimana diartikulasikan oleh Aristoteles (Lister, 2003).

Meskipun menurut Roche (1992), kewajiban kewarganegaraan saat ini ditafsirkan lebih luas sebagai "wacana tugas.” Wacana ini merefleksikan “pendekatan ketiga”, yakni komunitarian yang memiliki pertalian kuat dengan tradisi republik sipil, dengan asumsi dan kepedulian serupa yakni penolakan pada kewarganegaraan yang berbasis hak individu. Pada pendekatan hak, menekankan pada hak sipil, politik, dan sosial. Menurut Marshall, hak sipil merupakan hak yang diperlukan bagi kebebasan individu, diantaranya hak kebebasan bicara, berpikir, dan berkeyakinan; hak memiliki kekayaan, dan hak atas keadilan. Sementara hak politik adalah hak berpartisipasi dalam aktivitas politik, termasuk hak dipilih maupun memilih dalam pemilu. Sedangkan hak sosial adalah hak untuk memperoleh kesejahteraan, baik sosial maupun ekonomi.

Khusus tentang hak sosial, kelompok neoliberal menolaknya karena menyiratkan klaim atas sumber daya (Lister, 2003). Kelompok neoliberal mengatakan bahwa hak sosial tidak bisa disamakan dengan hak sipil dan hak politik. Namun penolakan neoliberal ini mendapatkan sejumlah sanggahan. Salah satunya adalah argumen bahwa hak sosial ini justru membantu mempromosikan penggunaan hak sipil dan politik yang efektif dari kelompok yang tidak diuntungkan secara kekuasaan maupun sumber daya.Peran yang diberikan hak sosial adalah pada pengakuan bahwa otonomi tidak dapat dipahami hanya soal individualistik murni, tapi juga memiliki dimensi sosial (Lister, 2003).

Beberapa kelompok feminis melihat pentingnya hak sosial dalam memperlemah kekuasaan patriarkal dan memperkuat posisi perempuan dalam kewarganegaraan politik. Namun kelompok feminis radikal tetap melihat pendekatan hak sebagai ekspresi dari nilai dan kekuasaan laki-laki. Skeptisme mereka ini sama dengan kelompok radikal yang menyoroti "gagalnya kewarganegaraan dalam lembaga demokrasi liberal untuk memenuhi kebutuhan perempuan dan kelompok rasial serta kelompok yang termarginalisasi secara sosial dan ekonomi” (Lister, 2003).Yang menarik, dalam pendekatan hak, juga usulan atas hak reproduksi. Menurut David Held, hak reproduksi adalah kemungkinan yang sangat mendasar 
dari partisipasi perempuan secara efektif dalam masyarakat sipil dan politik. Ia mengidentifikasikan tujuh gugus hak yang sesuai dengan kekuasaan, yakni kesehatan, sosial, budaya, sipil, ekonomi, pasifis, dan hak politik.

Menurut Lister, perbedaan pandangan politik merupakan upaya untuk menggunakan prosedur politik universalisme sebagai jalan untuk mengakomodasi perbedaan nilai dalam prosedur demokrasi. Agar proses ini dapat berjalan, maka ada dua syarat penting, yaitu penerapan sistem politik yang inklusif terhadap perbedaan nilai dan orientasi politik, serta gerakan emansipatoris dari perempuan agar dapat merepresentasikan diri sebagai gerakan politik (Lister, 1997). Lister melihat melalui dua hal ini terjadi proses renegoisasi antara dua ranah berbeda, sehingga tercipta analisis seimbang dan komprehensif, dengan merekonstruksi kembali pembedaan ruang tersebut. Menurut Lister, dikotomi ruang privat dan ruang publik ini bukanlah sesuatu yang rigid, melainkan suatu proses yang dinamik untuk mempertemukan kepentingan partikularisme baik dari laki-laki maupun perempuan agar menjadi kepentingan universalisme karena keterhubungan diantara.

Munculnya komunitarianisme yang sering disebut sebagai kebangkitan republik sipil merupakan reaksi melawan individualisme dari paradigma kewarganegaraan liberal yang telah mendominasi kehidupan politik kontemporer. Beberapa kelompok feminis tertarik dengan gambaran republik sipil tentang kewarganegaraan sebagai partisipasi politik aktif dan keterlibatan dalam pengambilan keputusan, serta potensi kolektif dalam ranah publik untuk mengartikulasikan kepentingan perempuan dan “kelompok minoritas” (Lister, 2003).

Feminisme adalah sebuah paham yang muncul ketika wanita menuntut untuk mendapatkan kesetaraan Hak yang sama dengan pria. Pengakuan tentang ketidak seimbangan gender, dengan peran wanita yang berada di bawah pria. Pada awal abad ke 18 dapat dikatakan sebagai awal dalam sejarah feminisme, walaupun sudah ada wanita yang melakukan debat untuk mendapatkan posisi yang di akui dalam masyarakat, feminisme belum terlalu banyak berkembang pada saat itu. Pada saat itu yang bermunculan adalah para wanita yang menulis karya yang menunjukan tuntutan mereka untuk mendapatkan persamaan hak, khususnya di dalam bidang pendidikan.

Perbedaan-perbedaan gender yaitu pada peran-peran yang berbeda yang dimainkan lakilaki dan perempuan dalam berbagai institusional. Peran-peran perempuan di institusi keluarga misalnya sebagai seorang ibu bagi anak dan istri bagi suaminya. Motif utama dari perspektif ini adalah pembagian kerja dilihat dari gender (laki-laki dan perempuan) di dalam institusi keluarga. Menjadi sebuah dilematis ketika dalam pemilihan karir antara menyesuaikan 
passion(kerja) dengan menjadi Ibu Rumah Tangga atau pula keduanya (berkarir dan menjadi ibu Rumah Tangga). Seharusnya perempuan dan lak-laki tidak ada beda dalam perlakuan.

Model republik klasik menganjurkan bahwa semua warga negara harus terlibat secara langsung dalam pemerintahan masyarakat. Sementara kebanyakan perempuan mempraktikkan politik dalam tingkat lokal. Lister (2003) melihat bahwa perempuan tetap bisa memainkan peran penting dalam ruang publik meski mereka hanya menonjol di tingkat lokal karena ruang publik bukan hanya politik formal. Ruang publik juga meliputi, apa yang disebut Jean Lecca, sebagai “waduk kewarganegaraan”: gabungan dari berbagai asosiasi sukarelawan dari masyarakat sipil

Jaringan masyarakat sipil ini bisa berkontribusi secara tidak langsung dalam pengambilan keputusan negara. Untuk kebanyakan perempuan, keterlibatan dalam organisasi komunitas atau gerakan sosial ini kerap kali lebih efektif dibanding bergabung dalam politik formal. Gould mengatakan, "jika setiap manusia dihargai sebagai agen dengan kapasitas kebebasan memilih dan pengembangan diri”, tidak akan ada pijakan bagi satu jenis kelamin untuk memiliki hak lebih besar dengan menggunakan kapasitasnya dibanding yang lain dan mendominasi satu kelompok melalui penyangkalan terhadap kondisi agen yang setara. Kebebasan penuh perempuan oleh karenanya terletak pada kemampuan mereka berpartisipasi dalam mengendalikan kondisi ekonomi dan sosial hidup mereka, dan juga bebas dari diskriminasi dan dominasi (Lister, 2003).

\section{Pembangunan Hukum Berkeadilan Gender}

Masyarakat yang modern yakni masyarakat yang sadar akan penggunaan hukum dalam kehidupannya. Hukum tidak hanya dipakai untuk mengukuhkan pola-pola kebiasaan dan tingkah laku yang terdapat dalam masyarakat, hukum mengarahkan kepada tujuan-tujuan yang dikehendaki, menghapus kebiasaaan yang tidak sesuai dengan kehidupan saat ini, menciptakan tata kehidupan yang baru. Raharjo (1987: 121) menjelaskan pandangan modern tersebut yakni penggunaan law as a tool atau penggunaan hukum sebagai alat. Dengan demikian hukum dapat dijadikan sebagai rekayasa sosial untuk mewujudkan pembangunan dan perlindungan akan HAM yang dalam hal ini menciptakan keadilan gender. Sistem hukum yang maju harus dengan pembuatan dan perkembangan hkum yang didesain secara profesional dan logis, tidak diragukan lagi bahwa produk hukum bisa mempengaruhi, bahkan mengubah setiap sendi kehidupan bermasyarakat, (Fuady, 2007: 61).

Sudah seharusnya dalam membangun hukum yang berkeadilan pada gender harus mengedepankan prinsip keadilan dan hak asasi manusia. Indonesia yang merupakan negara 
hukum. Negara hukum Indonesia mengandung prinsip antara lain norma yang bersumber pada Pancasila sebagai dasar negara, sistem pemerintahan yang konstitusional, kedaulatan rakyat atau prinsip demokrasi, prinsip persamaan kedudukan dalam hukum dan pemerintahan, adanya organ pembentuk undang-undang (DPR), sistem pemerintahan presidensiel, kekuasaan kehakiman yang bebas dan merdeka, hukum bertujuan untuk melindungi segenap bangsa Indonesia dan seluruh tumpah darah Indonesia, adanya jaminan akan hak asasi dan kewajiban dasar manusia, Winarno (2013: 150-151).

Hukum di Indonesia juga membentuk sistem hukum yang tersusun berdasarkan hukum tertinggi negara yaitu UUD 1945 kemudian dijabarkan ke dalam peraturan hukum yang lebih rendah sehingga bersifat hierarkis primadinal (Winarno, 2013: 149). Hierarki peraturan perundang-undangan menurut Pasal 7 Undang-Undang No. 12 Tahun 2011 yakni:

\section{UUD 1945}

2. Ketetapan MPR

3. UU/ Peraturan pemerintah pengganti undang-undang

4. Perarutan pemerintah

5. Peraturan presiden

6. Peraturan daerah propinsi

7. Peraturan daerah kabupaten/kota

Dengan demikian dalam pembangunan hukum Indonesia harus sesuai dengan hierarki tersebut, begitu pula dalam membangun hukum yang berkeadilan pada gender tidak lepas dari aturan awal yang diamanatkan dalam UUD 1945 yang mengedepankan hak asasi manusia. Sebagaimana yang dijelaskan dalam konvensi CEDAW yakni adanya kesetaraan subtantif, nondiskriminatif dan kewajiban negara yang tercermin dalam Pasal 6 sampai dengan Pasal 16 yaitu:

1. Penghapusan perdagangan orang dan ekspolitasi perempuan (Pasal 6);

2. Kesetaraan dalam kehidupan publik dan politik (Pasal 7);

3. Keterwakilan perempuan di ranah internasional (Pasal 8);

4. Kewarganegaraan (Pasal 9);

5. Pendidikan (Pasal 10);

6. Ketenagakerjaan (pasal 11);

7. Kesehatan (Pasal 12);

8. Kehidupan ekonomi dan sosial (Pasal 13);

9. Hak perempuan pedesaan (Pasal 14);

10. Persamaan di depan hukum (Pasal 15); 
11. Persamaan dalam perkawinan dan keluarga (Pasal 16).

Dalam prakteknya pembangunan hukum di Indonesia telah menyentuh 11 dasar prinsip kesetaraan menurut konvensi CEDAW tersebut. Namun yang perlu diperhatikan lagi yakni setiap manusia atau warga negara Indonesia berhak atas pemenuhan yang didasarkan peraturan perundang-undangan tersebut. Indikator yang harus diperhatikan bersama yakni, akses, partisipasi, kontrol dan manfaat (Kemenkumham, Kementerian Pemberdayaan Perempuan dan Perlindungan Anak, Kemendagri, 2012 : 41-43).

a. Akses

Mempertimbangkan cara untuk memperoleh kesempatan yang setara antara laki-laki dan perempuan untuk setiap sumber daya yang akan diatur dalam peraturan perundangundangan, dengan demikian peraturan atau norma hukum yang tercipta akan mencerminkan keadilan dan kesetaraan gender.

b. Partisipasi

Peraturan perundang-undangan sudah semestinya memberikan kesempatan yang setara bagi laki-laki dan perempuan dalam melaksanakan hak dan kewajibannya dalam setiap kebijakan dan program pembangunan yang dilakukan oleh pemerintah. Contohnya dalam menentukan pemecahan solusi yang dihadapi bersama.

c. Kontrol

Analisis pada norma hukum yang dirumuskan dalam peraturan perundang-undangan sudah memuat ketentuan yang setara berkenaan dengan hubungan kekuasaan antara laki-laki dan perempuan untuk melaksanakan hak dan kewajibannya sebagai seorang warga negara. Contohnya Undang-undang / Perda dan kebijakan nasional dan daerah yang menjamin terwujudnya kesetaraan dan keadilan bagi perempuan dan laki-laki.

d. Manfaat

Analisis pada norma hukum yang dirumuskan dapat menjamin bahwa suatu kebijakan atau program akan menghasilkan manfaat yang setara bagi laki-laki dan perempuan di kemudian hari. Contohnya hak perempuan untuk menikmati manfaat dari hasil kerjanya untuk diri sendiri dan keluarga.

\section{Penutup}

Persoalan ketidaksetaraan dan ketidakadilan gender bukanlah persoalan sederhana dan berdimensi lokal, namun persoalan ini ditemui di seluruh belahan dunia, serta berkaitan erat dengan segala sendi kehidupan manusia. Maka tidaklah mengherankan jika boleh dikatakan perjuangan para pemerhati masalah perempuan, untuk meningkatkan kesetaraan dan keadilan 
gender yang sudah sekian lama seolah-olah jalan di tempat, atau paling sedikit hasil yang dicapai belum sesuai dengan harapan. Dalam pelaksanaan pembangunan hukum Indonesia yang merupakan negara hukum sudah seharusnya mengedepankan prinsip kesetaraan dan keadilan dalam setiap sektor terutama dalam hal gender. Gender tidak hanya selalu mengenai jenis kelamin, namun lebih pada fungsi dalam kehidupan sosial budaya dalam masyarakat. Pemenuhan hak dan kewajiban yang seimbang atau setara antara laki-laki dan perempuan sudah seharusnya diperhatikan, dan juga harus memiliki payung hukum sendiri. Hal ini bertujuan untuk menciptakan keadilan sosial yang sesuai dengan cita-cita negara Republik Indonesia yang dijelaskan dalam pembukaan UUD 1945 dan Pancasila sebagai dasar negara. Hukum harus selalu ditegakkan di negara hukum yang berkeadilan sosial untuk setiap warga negaranya tanpa memandang status apapun, namun yang lebih tepat lagi perlu diperhatikan hak dan kewajiban bagi setiap orang yang berkewarganegaraan Indonesia baik laki-laki maupun perempuan. 


\section{DAFTAR PUSTAKA}

Arjani, N. L., 2008, Kesetaraan dan Keadilan Gender (KKG) dan Tantangan Global, Jurnal Ekonomi dan Sosial, 1 (2). 113-117.

Fakih, M, 1996, Analisis Gender dan Transformasi Sosial, Yogyakarta: Pustaka Pelajar.

Fuady, Munir, 2007, Sosiologi Hukum Kontemporer: Interaksi Hukum, Kekuasaan dan Masyarakat, Bandung: Citra Aditia Banti.

Lister, Ruth, 2003, Citizenship: Feminist Perspectives. Second Edition, New York: Palgrave Macmilan.

Kemenkumham, Kementerian Pemberdayaan Perempuan dan Perlindungan Anak dan Kemendagri, 2012, Parameter Kesetaraan Gender dalam Pembentukan Peraturan Perundang-Udangan, Jakarta.

Pujiastuti, 2012, Peluang PNS Perempuan Dalam Memperoleh Jabatan Struktural: Studi Kualitas Kesetaraan Gender Di Pemerintahan Kota Semarang, Jurnal POLITIKA, 3 (2). 68-83.

Puspitawati, Herien, 2010, Persepsi Peran Gender Terhadap Pekerjaan Domestik dan Publik Pada Mahasiswa IPB, Jurnal Studi Gender \& Anak, 5 (1). 17-34.

Rahardjo, S, 1987, Ilmu Hukum, Bandung: Alumni.

Suryani, E, 2010, Sosialisasi Kesetaraan Gender Pada Pegawai Kantor Kesejahteraan Sosial dan Pemberdayaan Masyarakat Kabupaten Bekasi, Jurnal FISIP Kybernan, 1 (2). 1-20.

Tong, Resmerie, 2004, Feminist Thoght, Yogyakarta: Jalasutra.

Winarno, 2013, Paradigma Baru Pendidikan Kewarganegaraan: Panduan Kuliah Di Perguruan Tinggi, Jakarta: Bumi Aksara.

Zakia, Rahima, 2011, Kesetaraan dan Keadilan Gender Dalam Adat Minangkabau, Jurnal Ilmiah Kajian Gender, 1 (1). 39-52. 